\title{
STUdI POTENSI WISATA CAGAR BUDAYA DESA SANGLIAT DOL
}

\author{
Edoardus Ayowembun ${ }^{1)}$, Suryono Herlambang ${ }^{2)}$, Jo Santoso ${ }^{3)}$ \\ 1)Program Studi S1 PWK, Fakultas Teknik, Universitas Tarumanagara, edoardus.@stu.untar.ac.id \\ 2)Program Studi S1 PWK, Fakultas Teknik, Universitas Tarumanagara, suryonoh@ft.untar.ac.id \\ 3)Program Studi S1 PWK, Fakultas Teknik, Universitas Tarumanagara, josantosojkt@gmail.com
}

Masuk: 19-08-2021, revisi: 24-08-2021, diterima untuk diterbitkan: 23-10-2021

\begin{abstract}
Abstrak
Desa Sangliat Dol merupakan salah satu desa wisata yang terletak di kecamatan Wertamrian, Kabupaten Kepulauan Tanimbar dengan luas wilyah $20 \mathrm{Ha}$. Desa Sangliat Dol merupakan wilayah desa wisata yang terdapat dalam Rencana Pengembangan Kawasan pariwisata di wilayah Kabupaten Kepulauan Tanimbar serta tertulis dalam RTRW Kabupaten Maluku Tenggara Barat 2012-2032 sebagai Kawasan Wisata Budaya. Kawasan Wisata Budaya dikembangkan dibeberapa desa, sebagai desa adat tua yang masih memiliki peran penting dalam struktur budaya Kabupaten Maluku Tenggara Barat. Desa Sangliat Dol juga ditetapkan sebagai Kawasan Pengembangan Pariwisata Nasional (KPPN) Tanimbar. Namun potensi dan daya Tarik yang dimiliki oleh Desa Sangliat Dol berupa pemandangan alam, adat istiadat yang masih melekat erat, serta peninggalan - peninggalan sejarah ini belum dimanfaatkan dengan maksimal sehingga jika dikembangkan dengan baik dapat meningkatkan minat wisatawan domestik maupun wisatawan mancanegara untuk datang berkunjung ke Desa Sangliat Dol. Penulis melakukan beberapa analisis seperti analisis penentuan cagar budaya, analisis lokasi, analisis tapak kawasan, analisis best practice serta analisis usulan pendekatan pengembangan wisata cagar budaya sehingga menghasilkan usulan untuk konsep pengembangan Kawasan Wisata Desa Sangliat Dol demi tercapainya Kawasan wisata Cagar budaya yang berkelanjutan dan diminati wisatawan.
\end{abstract}

Kata Kunci : Cagar Budaya; Wisata; Adat-istiadat; pendekatan Ekowisata.

\begin{abstract}
Sangliat Dol Village is one of the tourist villages located in Wertamrian sub-district, Tanimbar Islands Regency with an area of 20 hectares. Sangliat Dol Village is a tourist village area contained in the Tourism Area Development Plan in the Tanimbar Islands Regency and is written in the RTRW of West Southeast Maluku Regency 2012-2032 as a Cultural Tourism Area. The Cultural Tourism Area was developed in several villages, as an old traditional village that still has an important role in the cultural structure of West Southeast Maluku Regency. Sangliat Dol Village is also designated as the National Tourism Development Area (KPPN) of Tanimbar. However, the potential and attraction possessed by Sangliat Dol Village in the form of natural scenery, customs that are still closely attached, and historical relics have not been utilized to the maximum so that if developed properly it can increase the interest of domestic and foreign tourists to come to visit the village. Sangliat Dol. The author conducts several analyzes such as analysis of determining cultural heritage, location analysis, area footprint analysis, best practice analysis and analysis of proposed approaches to developing cultural heritage tourism so as to produce proposals for the concept of developing the Sangliat Dol Village Tourism Area in order to achieve a sustainable cultural heritage tourism area and attract tourists .
\end{abstract}

Keywords: Cultural Conservation; Tourism; Customs; Ecotourism approach.

\section{PENDAHULUAN}

Latar Belakang

Salah satu tolak ukur tinggi rendahnya peradaban suatu bangsa dapat dilihat dari tinggalan situs bersejarahnya. Indonesia merupakan negara kepulauan terbesar di dunia yang kaya akan ragam 
budaya. Salah satu wilayah yang memiliki keanekaragaman budaya dan warisan artefak yang masih mempunyai nilai budaya yang tinggi di Indonesia Timur adalah Provinsi Maluku, Kabupaten Kepulauan Tanimbar.

Salah satu upaya yang dilakukan oleh Pemerintah Daerah Provinsi Maluku dan Pemerintah Kabupaten Kepulauan Tanimbar demi mewujudkan Undang - Undang Nomor 10 Tahun 2009 tersebut adalah melalui pengembangan Desa Sangliat Dol, Kecamatan Wertamrian Kabupaten Kepulauan Tanimbar, Provinsi Maluku sebagai desa wisata budaya. Desa Sangliat Dol secara administratif merupakan kawasan pariwisata yang terdapat di kecamatan Wertamrian, Kabupaten Kepulauan Tanimbar. Kawasan desa wisata Sangliat Dol memiliki luas wilayah 20 ha dan terdapat 776 jiwa atau 212 kk yang bermukim di desa tersebut ${ }^{11}$.

Didukung dengan kebijakan-kebijakan daerah, Rencana Pengembangan Kawasan pariwisata di wilayah Kabupaten Kepulauan Tanimbar dalam RTRW Kabupaten Maluku Tenggara Barat 2012-2032 adalah sebagai Kawasan Wisata Budaya. Kawasan Wisata Budaya dikembangkan di beberapa desa, sebagai desa adat tua yang masih memiliki peran penting dalam struktur budaya Kabupaten Maluku Tenggara Barat. Dalam RIPPARNAS (PP No.50/2011) Kabupaten Maluku Tenggara Barat masuk ke dalam Destinasi Pariwisata Nasional (DPN) Ambon - Banda Naira dan sekitarnya, serta ditetapkan sebagai Kawasan Pengembangan Pariwisata Nasional (KPPN) Tanimbar dan sekitarnya2).

Dengan adanya tugas akhir ini, penulis terpacu untuk melakukan penelitian di Desa Sangliat Dol, Kecamatan Wertamrian, Kabupaten Kepulauan Tanimbar Dengan melihat banyak banyak daya tarik yang berupa pemandangan alam, adat istiadat yang masih melekat erat, serta peninggalan peninggalan sejarah masih dijaga oleh masyarakat Desa Sangliat Dol serta penulis merupakan putra desa Desa Sangliat Dol, sehingga niat untuk memilih Desa Sangliat Dol sangat besar dikarenakan penulis berkeinginan mengembangkan wisata yang ada di Desa Sangliat Dol. Namun dari sekian banyak daya tarik yang ada di Desa Sangliat Dol penulis memilih peninggalan bersejarah sebagai fokus utama, sedangkan daya tarik lainnya sebagai penunjang.

Namun terdapat beberapa masalah yang ditemukan penulis di Desa Sangliat Dol. Masalah tersebut tampaknya membuat kawasan daya tarik di Desa Sangliat Dol semakin lama semakin kurang diminati sehingga perlu ada strategi untuk meningkatkan minat dari wisatawan untuk berwisata di Desa Sangliat Dol.

\section{Rumusan Permasalahan}

Berdasarkan latar belakang yang dikemukakan penulis melakukan perumusan masalah dengan beberapa pertanyaan penelitian sebagai berikut: Desa Sangliat Dol memiliki nilai - nilai budaya dan peninggalan situs bersejarah yang patut dilestarikan, oleh karena itu perlu dikaji lebih dalam mengenai nilai - nilai budayanya. Kedua Desa Sangliat Dol memiliki potensi yang baik namun belum dikelola dengan baik.

Berdasarkan masalah di atas, maka penulis memiliki beberapa pertanyaan peneliti, yaitu: Apa kekayaan budaya Desa Sangliat Dol yang dapat menjadi keunggulan, sehingga Desa Sangliat Dol dapat diajukan sebagai kawasan cagar budaya? Dan Bagaimana penerapan konsep ekowisata untuk mengembangkan desa wisata berbasiskan cagar budaya 3 '?

\section{Tujuan}

Mengetahui persepsi wisatawan dan masyarakat mengenai nilai - nilai budaya, serta tanggapan masyarakat mengenai cagar budaya dan partisipasi masyarakat dalam membangun desa Sangliat Dol. Berikut Mengusulkan wisata cagar budaya serta pendekatan ekowisata. 


\section{KAJIAN LITERATUR}

Penelitian ini adalah penelitian yang berangkat dari keingintahuan mengenai nilai signifikansi warisan budaya guna memenuhi kriteria cagar budaya yang disebutkan dalam Undang - Undang RI No. 11 Tahun 2010 Tentang Cagar Budaya.

\section{Nilai Signifikansi}

Signifikansi budaya artinya nilai-nilai estetika, historis, ilmiah, sosial atau spiritual untuk generasi dahulu, kini atau masa datang.

Definisi dari nilai-nilai signifikansi budaya dijelaskan dalam Guidelines to the Burra Charter (Australia ICOMOS Inc, 1988:12) dengan poin- poin sebagai berikut : Nilai Estetika, Nilai Sejarah, Nilai IImu Pengetahuan, Nilai Sosial atau spiritual.

\section{Cagar Budaya}

Undang-Undang Republik Indonesia Nomor 11 Tahun 2010 menyebutkan definisi cagar budaya adalah warisan budaya bersifat kebendaan berupa benda cagar budaya, bangunan cagar budaya, struktur cagar budaya, situs cagar budaya, dan kawasan cagar budaya di darat dan/atau di air yang perlu dilestarikan keberadaannya karena memiliki nilai penting bagi sejarah, ilmu pengetahuan, pendidikan, agama, dan/atau kebudayaan melalui proses penetapan.

Disebutkan pula dalam Undang-Undang Republik Indonesia Nomor 11 Tahun 2010 Tentang Cagar Budaya kriteria dari cagar budaya adalah :

a. Berusia 50 (lima puluh) tahun atau lebih.

b. Mewakili masa gaya paling singkat berusia 50 (lima puluh) tahun.

c. Memiliki arti khusus bagi sejarah, ilmu pengetahuan, pendidikan, agama, dan/atau kebudayaan.

d. Memiliki nilai budaya bagi penguatan kepribadian bangsa.

\section{Zona Pelestarian Cagar Budaya}

Undang-Undang No. 11 Tahun 2010 pasal 72 mengatur mengenai penetapan batas-batas keluasan dan pemanfaatan ruang dalam situs dan kawasan berdasarkan kajian. Sistem zonasi dapat terdiri dari:

a. Zona inti : area perlindungan utama untuk menjaga bagian terpenting cagar budaya

b. Zona penyangga : area yang melindungi zona inti.

c. Zona pengembangan : area yang diperuntukan bagi pengembangan potensi cagar budaya bagi kepentingan rekreasi, daerah konservasi lingkungan alam, lansekap budaya, kehidupan budaya tradisional, keagamaan, dan kepariwisataan.

d. Zona penunjang : area yang diperuntukkan bagi sarana dan prasarana penunjang serta untuk kegiatan komersial dan rekreasi umum.

\section{Teori Pariwisata}

Pengertian pariwisata berdasarkan UU RI No. 10 tahun 2009 tentang Kepariwisataan menyebutkan bahwa pariwisata adalah: "berbagai macam Kegiatan Wisatawan dan dukungan berbagai fasilitas serta layanan yang disediakan oleh masyarakat, pemerintah, dan pemerintah daerah.

\section{Tipologi Culture Tourism}

Menurut Muster $(1996,2007)$ secara umum, tipologi pariwisata di kategorikan : Attraction, Event, Zona Pelestarian Cagar Budaya.

\section{Ekowisata}

Menurut (Goodwin, 1997). ekowisata merupakan wisata alam berdampak ringan yang menyebabkan terpeliharanya spesies dan habitatnya secara langsung dengan peranannya dalam pelestarian dan atau secara tidak langsung dengan memberikan pandangan kepada masyarakat setempat, untuk membuat masyarakat setempat dapat menaruh nilai, dan melindungi wisata alam dan kehidupan lainnya sebagai sumber pendapatan. 


\section{Prinsip Ekowisata}

Sebagaimana dimaksud dalam pasal 2 permendagri No. 33 tahun 2009 tentang pengembangan ekowisata berbasis masyarakat dan konservasi, yakni : Kesesuaian antara jenis dan karakteristik ekowisata, Konservasi, Ekonomis, Edukasi, Memberikan kepuasan dan pengalaman kepada pengunjung, Partisipasi masyarakat, dan Menampung kearifan lokal.

\section{METODE}

Pada penelitian ini menggunakan kedua Teknik yang terdapat dalam proses pengumpulan data yaitu pengumpulan data primer dan pengumpulan data sekunder. Penjabaran sebagai berikut: Jenis data Primer dan Jenis Data Sekunder. Teknik pengumpulan data primer sebagai berikut, Survei Lapangan dan Wawancara. Teknik Pengumpulan Data Sekunder Data ini diperoleh dari sumber lain terkait objek studi. Dalam penelitian ini data sekunder diperoleh dari berbagai sumber yang relevan seperti studi literatur, skripsi/tesis, internet, pemerintah desa, tokoh adat, pemerintah terkait.

\section{DISKUSI DAN HASIL}

\section{Analisis Penentuan Cagar Budaya}

Pada bagian ini akan membahas mengenai kriteria - kriteria yang dapat menjadikan tempat objek studi sebagai bagian dari cagar budaya seperti:

\section{1) Potensi Budaya}

Potensi budaya adalah potensi berupa keadaan keadaan aktivitas masyarakat dan budaya secara keseluruhan. Potensi budaya dikategorikan penulis menjadi dua, yaitu potensi tidak berwujud dan potensi berwujud.

\section{2) Syarat dan Kriteria Cagar Budaya}

Merujuk kepada gudegnet (6/9) Wiwit Kasiyati selaku Kasi Perlindungan, Pengembangan dan Pemanfaatan BPCB DIY menjelaskan, "Syarat dan kriteria suatu bangunan atau kawasan menjadi cagar budaya sudah ditetapkan dalam Undang-Undang RI Nomor 11 Tahun 2010 Mengenai Cagar Budaya. "Benda, bangunan, atau struktur dapat diusulkan sebagai benda cagar budaya, bangunan cagar budaya, atau struktur cagar budaya apabila memenuhi kriteria:

1. Berusia 50 tahun atau lebih

2. Mewakili masa gaya paling singkat berusia 50 tahun

3. Memiliki arti khusus bagi sejarah, ilmu pengetahuan, pendidikan, agama, dan/atau kebudayaan.

4. Memiliki nilai budaya bagi penguatan kepribadian bangsa.

Satuan ruang geografis dapat ditetapkan sebagai kawasan cagar budaya apabila:

1. Mengandung 2 situs cagar budaya atau lebih yang letaknya berdekatan.

2. Berupa lanskap budaya hasil bentukan manusia berusia 50 tahun

3. Memiliki pola yang memperlihatkan fungsi ruang pada masa lalu berusia paling sedikit 50 tahun

4. Memperlihatkan pengaruh manusia masa lalu pada proses pemanfaatan ruang berskala luas

5. Memperlihatkan bukti pembentukan lanskap budaya

6. Memiliki lapisan tanah terbenam yang mengandung bukti kegiatan manusia atau endapan fosil

Dilihat dari benda, bangunan, atau struktur yang dijelaskan dalam Undang-Undang RI Nomor 11 Tahun 2010 Mengenai Cagar Budaya, serta satuan ruang geografis, dapat disimpulkan bahwa peninggalan situs bersejarah di Desa Sangliat Dol memiliki potensi yang cukup baik menjadi kawasan cagar budaya. Potensi - potensi tersebut akan dijabarkan pada bagian potensi lokasi.

\section{3) Daya Tarik}

Berikut melalui dokumen Perencanaan Rancangan Pembangunan Rumah Adat, telah mengidentifikasi empat belas (14) aset wisata seperti: Bati Rusuk, We-Megane, Bat Karat Keri, WeLempit, Gapura Utama, Lingat, Titar (Tangga Batu), Natar Sori ( Perahu Batu), Rumah Adat (Rumah 
Tua), We-Loloby, Tumpur Da, Batfian, Karyae Ain, Laran Tukar dan Awol Ni Weye.

Dari empat belas daya tarik tersebut ditemukan beberapa lokasi yang sering di kunjungi dan terawat, lokasi - lokasi tersebut akan dijabarkan dalam pembahasan survei lapangan berikut ini

\section{4) Survei Lapangan}

Berdasarkan hasil survei lapangan ditemukan beberapa lokasi yang berpotensi sebagai usulan untuk menjadi kawasan cagar budaya. Potensi potensi lokasi tersebut dapat dijabarkan sebagai berikut;

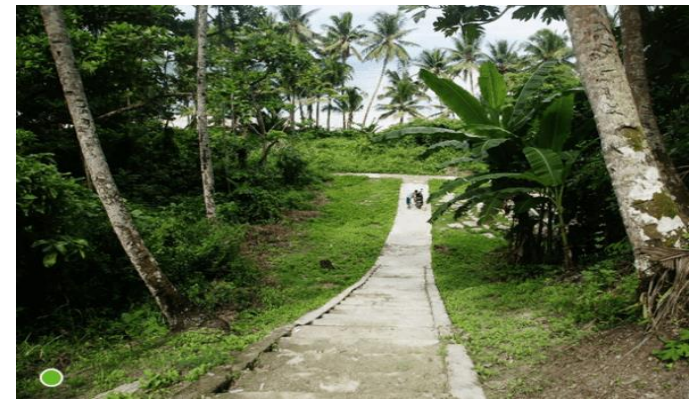

Bentang Alam

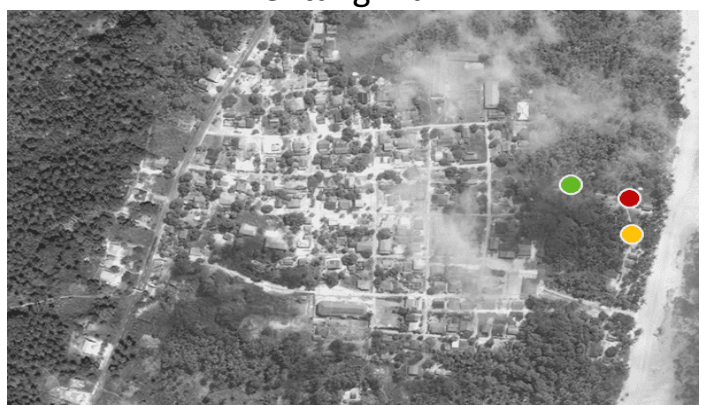

Peta Sebaran DTW

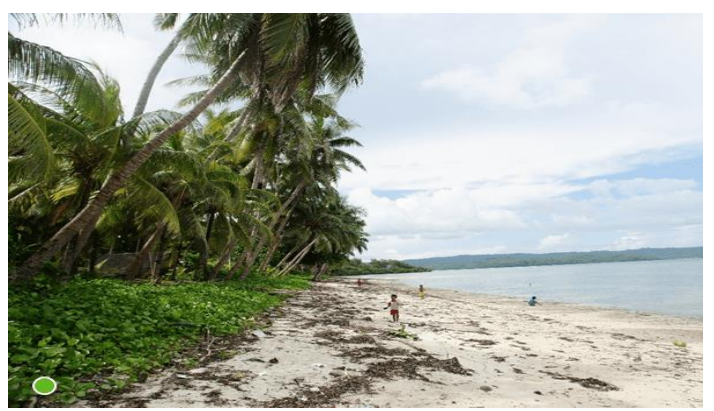

Pantai

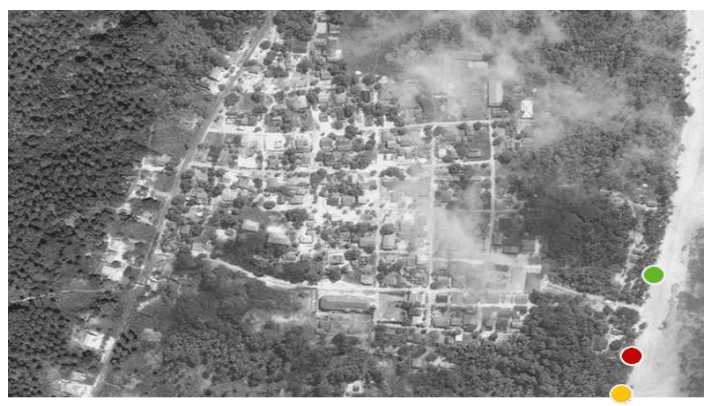

Peta Sebaran DTW

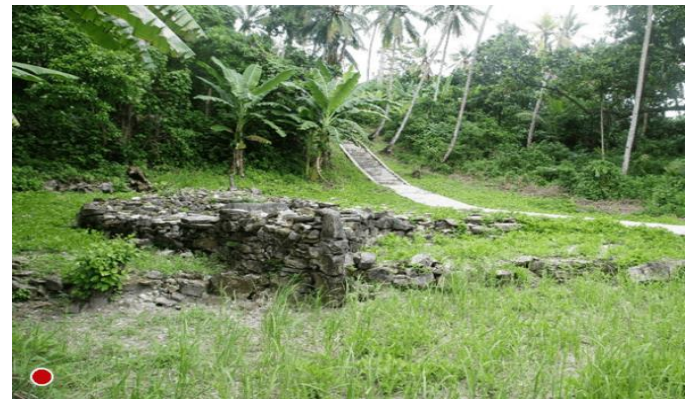

Welempit

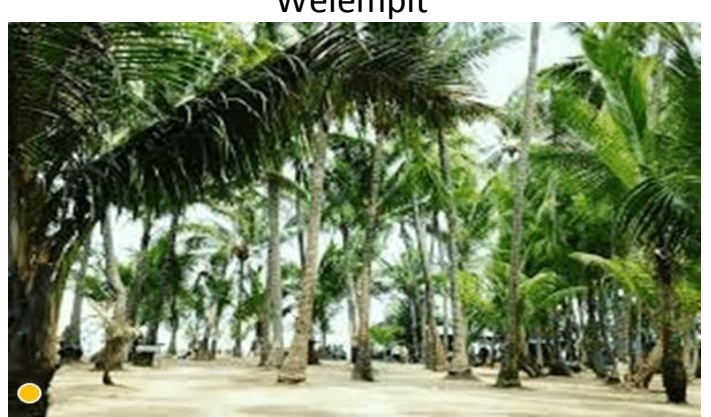

Pantai Kelapa

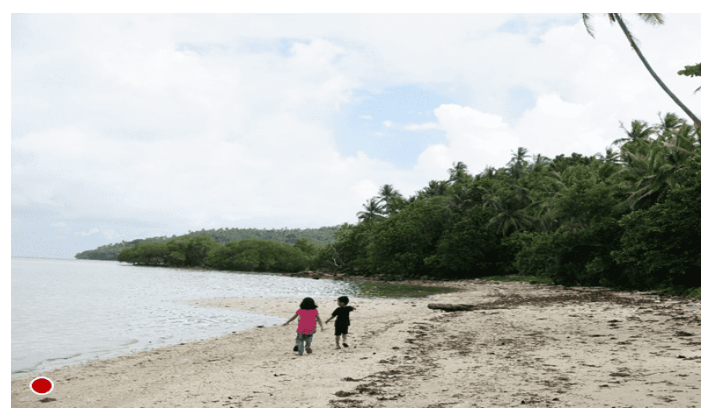

Pantai

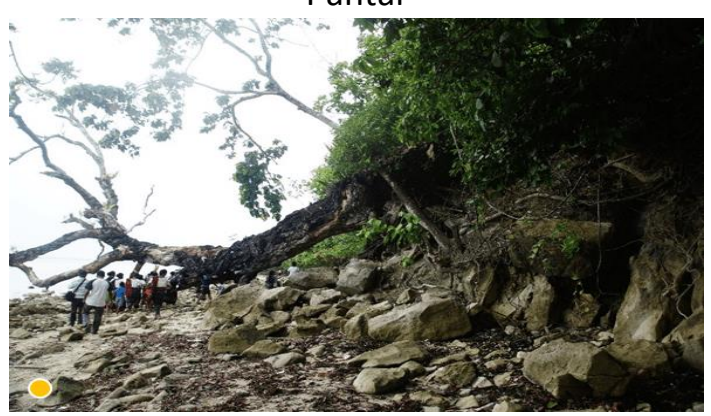

Welolobi 

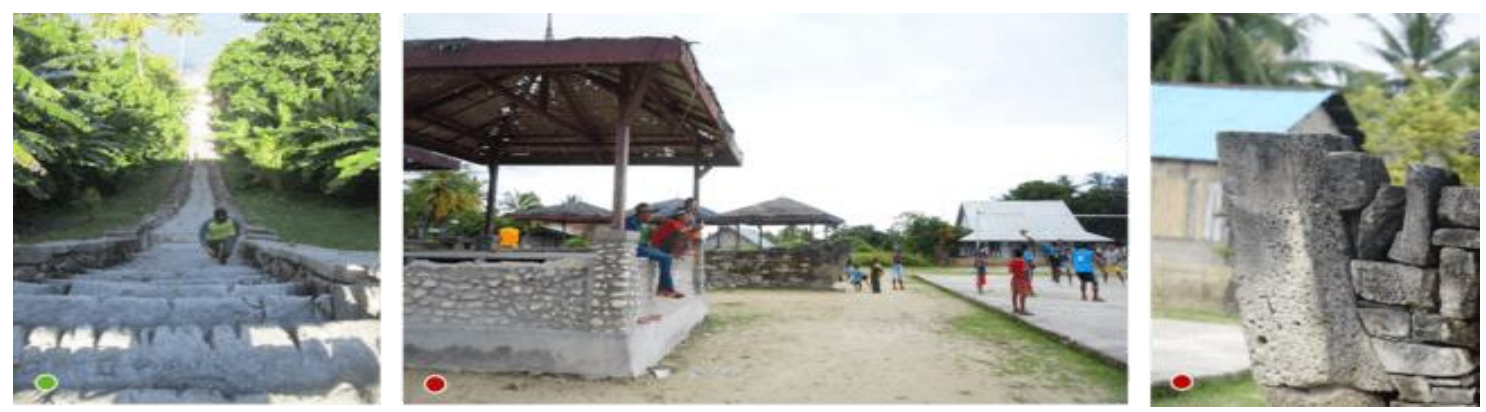

Area Titar dan Natar Sori

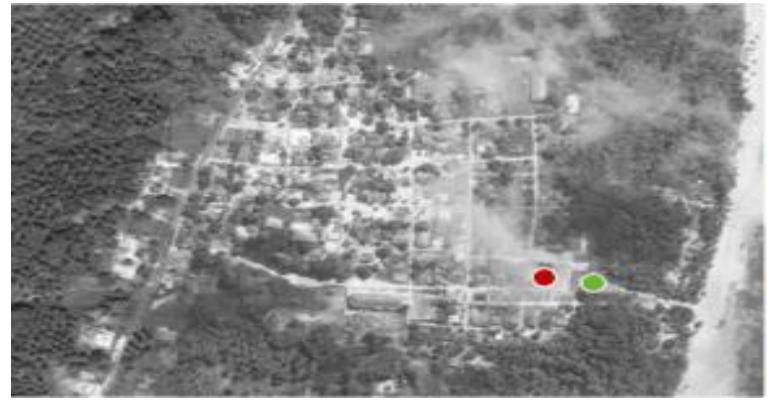

Peta Sebaran DWT

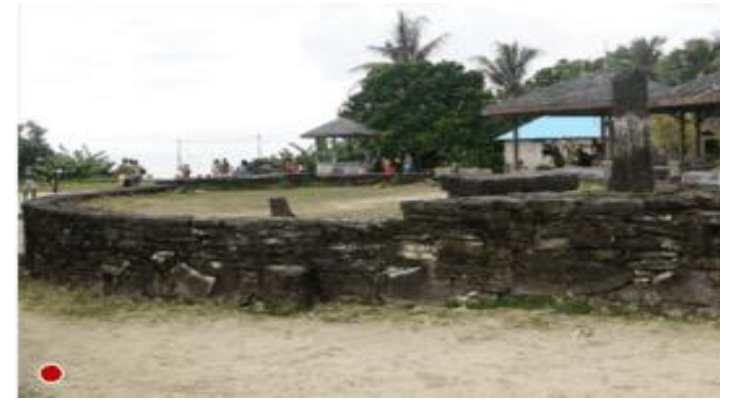

Natar Sori

Gambar 1. Gambar Daya Tarik

Sumber: Survei Sekunder, 2021

\section{5) Potensi Lokasi}

Dari hasil survei yang dilakukan dengan penilaian terhadap kriteria - kriteria yang dipilih terdapat tiga daya tarik yang memiliki potensi dan dipilih sebagai kawasan prioritas wisata cagar budaya di Desa Sangliat Dol dan diidentifikasi sebagai lokasi yang memiliki dasar pengembangan pariwisata dan cukup siap dalam mengakomodasi pengembangan baru. Ketiga lokasi tersebut adalah:

1. Natar Sori ( Perahu Batu)

2. Titar ( Tangga Batu)

3. Welempit ( Sumur di Tengah Perahu Batu)

Tabel 1. Penentuan kriteria Potensi

\begin{tabular}{|c|c|c|}
\hline No & Kritria & Keterangan \\
\hline 1 & Nilai Budaya & $\begin{array}{l}\text { Natar sori memiliki nilai budaya yang luruh sehingga tempat ini sering di gunakan } \\
\text { sebai ritual adat dan upacara - upacara penting lainnya. } \\
\text { Titar atau tangga batu memberikan pelajaran bagi manusia menunjukan sifat dan } \\
\text { tahap kehidupan seorang manusi. } \\
\text { Welwmpit merupakan sebuah nama dari sumber air yang dekat dengan pantai } \\
\text { warga mempercayai welempit sebagai air susu ibu, dimana memberikan pelajaran } \\
\text { bagi setiap generasi bahwa dimanapun mereka berada, jangan sampai melupakan } \\
\text { disanalah mereka dibesarkan oleh seorang ibu yang selalu menunggu kepulangan } \\
\text { dari mereka. }\end{array}$ \\
\hline 2 & Masyarakat & $\begin{array}{l}\text { Kesiapan masyarakat dalam membangun kawasan mereka sangat terlihat dari } \\
\text { partisipasi mereka dari kebiasan menerima siapapun yang datang ke tempat } \\
\text { mereka, sangat rama bagi pendatang baru atau pengunjung, gotong royong yang } \\
\text { masih di pengang teguh dan mau untuk belajar. }\end{array}$ \\
\hline 3 & Pemerintah & $\begin{array}{l}\text { Dalam dokumen RTRW Kabupaten Maluku Tenggara barat } 2012 \text { - } 2032 \text { ditetapkan } \\
\text { sebagai kawasan wisata budaya. Lanjut dalam RIPPARNAS (PP No. 50/2011) MTB } \\
\text { Masuk dalam Destinasi Pariwisata Nasional (DPN). Serta ditetapkan sebagai } \\
\text { Kawasan Pengembangan Pariwisata Nasional (KPPN) Tanimbar dan sekitarnya. }\end{array}$ \\
\hline 4 & Akses & $\begin{array}{l}\text { Aksesibilitas dalam kawasan terbilang baik hanya dengan jenis jalan berbeton, dan } \\
\text { lebar jalan lebih dari } 2 \text { meter }\end{array}$ \\
\hline
\end{tabular}




\section{Analisis Lokasi}

Analisis lokasi lebih bersifat makro dan meneliti faktor - faktor eksternal yang mempengaruhi kondisi kawasan. Berikut faktor - faktor yang akan di lihat:

\section{Batas Administrasi}

Kawasan perahu batu (Fampompar), tangga batu (Titar) dan Welempit sebgai objek studi terletak di Desa Sangliat Dol, Kecamatan Wertamrian, Kabupaten Kepulauan Tanimbar. Berikut batas - batas kawasan objek studi di Desa Sangliat Dol:
- Sebelah Utara
: Desa Krawain
- Sebelah Timur
: Laut Arafura
- Sebelah Selatan
: Desa Amdasa
- Sebelah Barat
: Hutan Maktian

\section{Aksesibilitas}

Aksesibilitas menuju Kawasan Warisan Budaya Desa Sangliat Dol, direkomendasikan untuk mengendarai kendaraan pribadi seperti kendaraan beroda empat dan kendaraan roda dua karena jarak tidak terlalu jauh namun waktu operasi kendaraan umum menuju Desa Sangliat Dol sangat terbatas dalam sehari kendaraan umum hanya beroperasi pada pagi dan sore hari. Ada pun dari Jakarta menuju Kawasan Wisata Cagar Budaya Desa Sangliat Dol dapat menggunakan transportasi udara dan laut. Bagi Pengunjung yang menggunakan kendaraan umum dapat melalui terminal omele Kota Saumlaki. Kendaran yang tersedia adalah kendaraan bermotor roda 4 dengan tarif Rp 20.000/orang dengan waktu tempuh 56 menit sedangkan bagi yang menggunakan jasa tumpangan kendaraan bermotor roda 2 dikenai tarif $\mathrm{Rp} 150.000$ dengan waktu tempuh 45 menit. Berikut gambaran kendaraan umum yang melayani rute Saumlaki - Sangliat Dol :
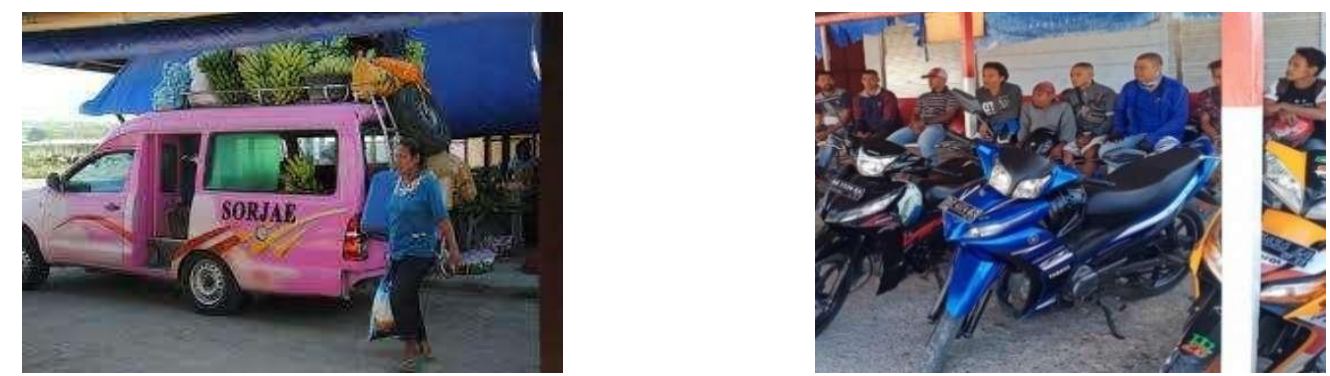

Gambar 2. Akses Kendaraan

Sumber: Survei Primer, 2021

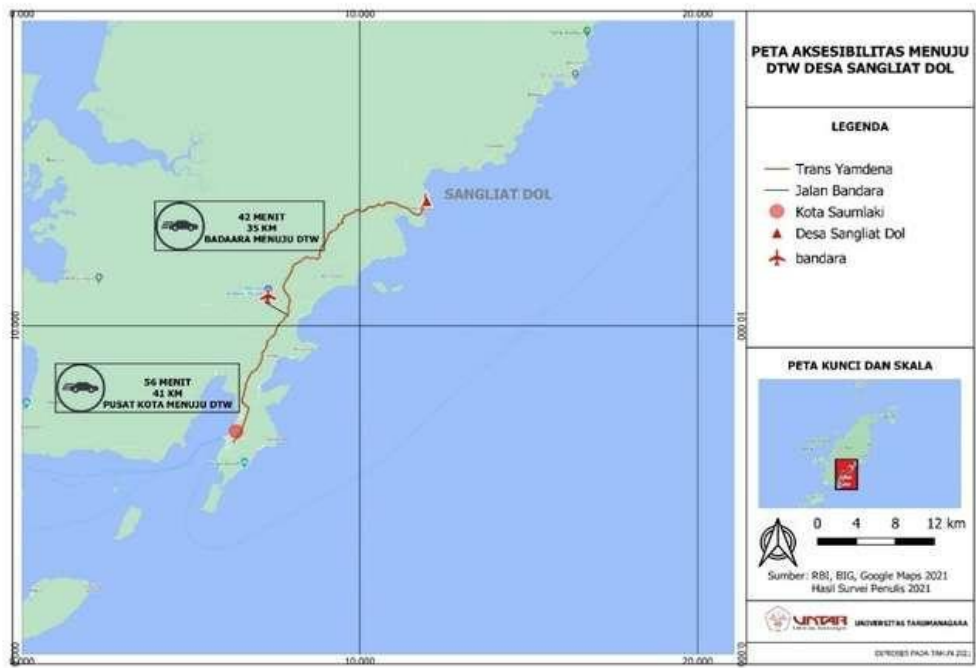

Gambar 3. Aksesibilitas menuju DTW Desa Sangliat Dol Sumber: Olahan Penulis 2021 
Kondisi Jalan

a. Jalan Raya yakni trans yamdena cukup baik sebab tidak begitu berkelok - kelok, dengan lebar jalan $6 \mathrm{~m}$.

b. Jalan Lokal dimana akses di dalam kawasan warisan budaya di Desa Sangliat Dol cukup baik $\pm 2,5 \mathrm{~m}$. kondisi jalan menggunakan material beton.

\section{Jenis Wisata yang Bisa Dikembangkan}

Pernyataan Makna Kultural atau stating cultural significance menurut Piagam Burra (Burra Charter) 1981, meliputi penilaian dari segi estetika, sejarah, nilai ilmiah dan nilai sosial yang kesemuanya ini merupakan proses suatu tempat agar makna kulturalnya dapat tetap terpelihara dengan baik Terdapat 14 (empat belas) lokasi wisata yang sebagian besar perlu perbaikan dan diidentifikasi posisi serta lokasinya. Diantara 14 (empat belas) lokasi wisata terdapat 3 lokasi penting yang bias di kembangkan dan memiliki cultural significance. Lokasi - lokasi tersebut antara lain:

\section{a) Perahu Batu ( Natar Sori )}

Sudah cukup banyak referensi yang membahas mengenai perahu batu di Desa Sangliat Dol. Monument ini sudah terkenal dan menjadi salah satu ikon budaya di Kepulauan tanimbar. Penduduk Sangliat Dol mengenal Natar ini dengan nama Fampompar. Monument ini memiliki panjang 18 meter dengan lebar 9 meter dan ketinggian 1,64 meter. Fampompar konon disusun atau dibangun oleh 6 (enam) matarumah saat itu.

Tampak Depan

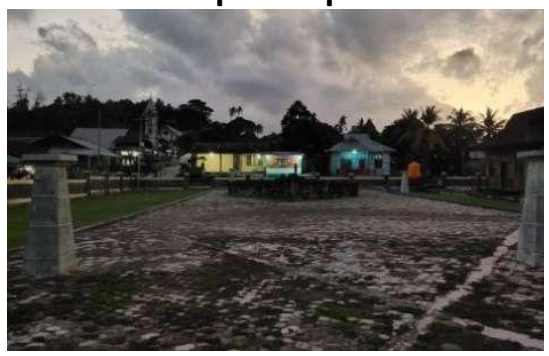

Tampak Belakang

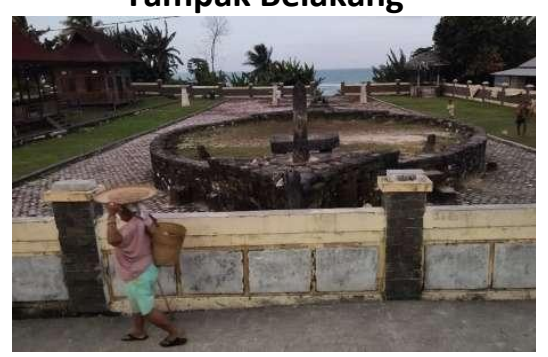

Tampak Samping

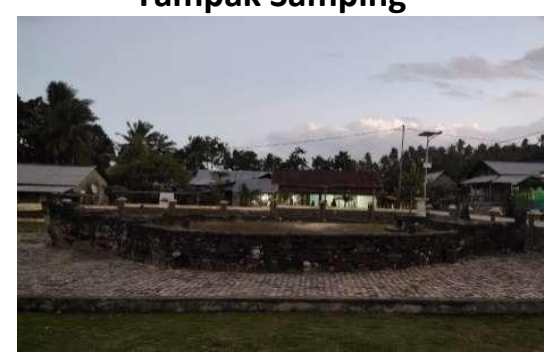

Gambar 4. Perahu Batu (Fampompar) Desa Sangliat Dol

Sumber: survei Penulis 2021

Adapun fungsi dari Fampompar iyalah sebagai tempat berdiskusi, tempat pelaksanaan adat dan kegiatan - kegiatan lainnya seperti sosial, ekonomi, bahkan politik. Dikarenakan tempat ini begitu sakral bagi masyarakat oleh karena itu apabila ada kesalahan ketika upacara berlangsung di Natar atau Fampompar maka akan turun hujan. Turunnya hujan di percaya masyarakat bahwa hati dan pikiran seseorang atau kelompok tertentu tidaklah bagus.

\section{b) Tangga Batu ( Titar )}

Tangga Batu atau lebih dikenal oleh masyarakat dengan nama Titar yang memiliki 108 anak tangga yang tersusun dari batu. Perahu Batu dibangun berdasarkan perjalanan kehidupan manusia secara jasmani dan rohani. Ada beberapa arti dan makna yang dapat dipelajari dari susunan Tangga Batu sebagai berikut:

a. Manusia lahir sebagai bayi yang polos, suci dan murni hal ini digambarkan dalam bentuk susunan tangga batu pertama, dengan susunan Tangga Batu yang rapi dan sempurna.

b. Tahapan remaja yang labil dan sering nakal digambarkan dengan bentuk Tangga Batu yang yang kedua. Dimana batu - batu itu hanya di hamburkan dan tidak beraturan.

c. Tahap dewasa adalah tahap dimana seseorang menentukan jalan hidupnya sendiri dengan mulai menata masa depannya agar menjadi sukses baik dalam pekerjaan maupun dalam urusan rumah tangga kelak itulah bagian dari susunan tangga batu ketiga. 
d. Manusia setelah dewasa dalam memiliki pekerjaan dan memiliki berkeluarga itu artinya orang tersebut telah mencapai titik dimana telah diakui sebagai orang yang layak dihormati. Itulah bentuk terakhir yang digambarkan pada susunan Tangga Batu.

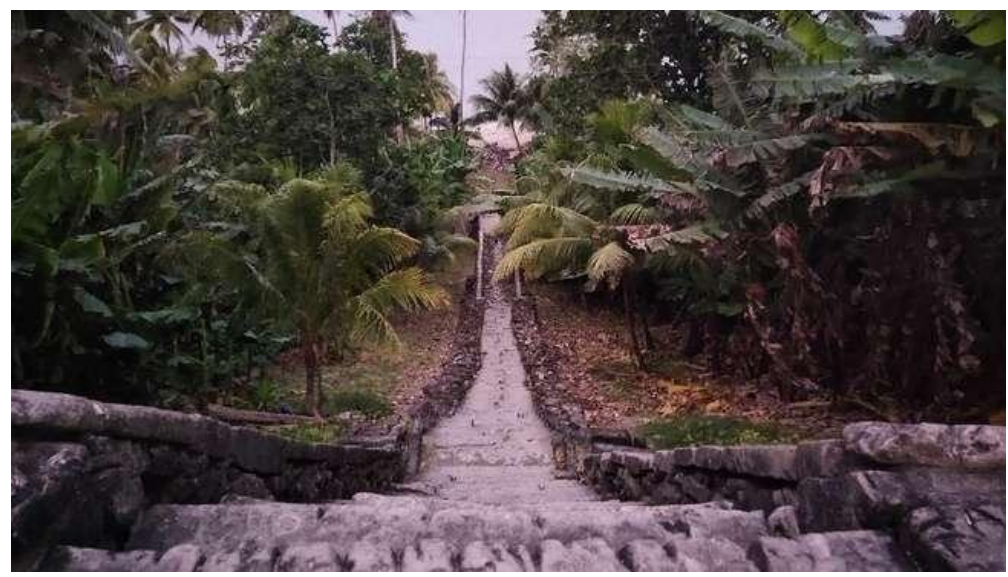

Gambar 5. Tangga Batu

\section{c) Sumur di Tengah Perahu Batu ( We-Lempit)}

Sumber : survei Penulis; 2021

Welempit adalah susunan batu berbentuk perahu, ditengah terdapat sebuah sumur yang sangat dekat dengan pantai kurang lebih 20 meter dari permukaan laut (MDPL) dengan kedalaman 7 meter memiliki kualitas air yang jernih dan dapat dikonsumsi langsung. sumur ini dipercaya masyarakat setempat sebagai Air Susu Ibu dimana ketika ada tamu yang berkunjung dan telah mengikuti upacara adat, setelah itu minum air dari sumur Welempit maka dia akan dianggap sebagai bagian dari masyarakat desa, adapun dampak bagi seorang tamu jika niat dan hati seseorang tidak baik maka akan tertimpa musibah.

Berdasarkan analisis lokasi maka karakter wisata yang terlihat adalah Budaya dan sejarah. Dikarenakan peninggalan benda bersejarah nilai -nilai kebudayaan yang sangat dominan dan berdampak baik bagi kehidupan masyarakat di Desa Sangliat Dol dengan ini penulis ingin mengusulkan kawasan menjadi wisata cagar budaya.

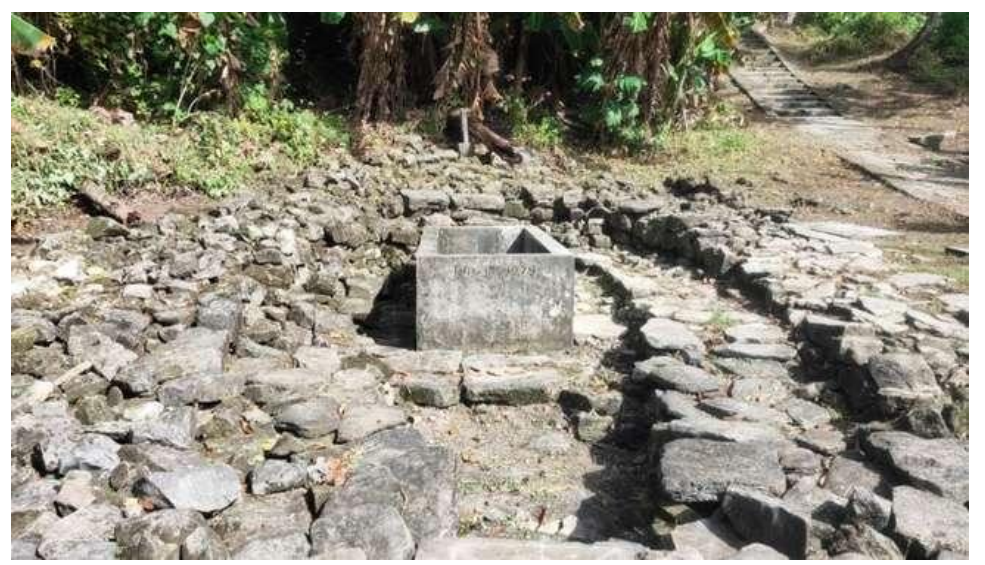

Gambar 6. Welempit

Sumber: survei Penulis 2021

\section{Analisis Tapak Kawasan}

Analisis tapak lebih bersifat mikro dan mencakup faktor internal dalam tapak. Hal ini bertujuan untuk melihat karakteristik lingkungan di dalam tapak kawasan sehingga dapat membantu penulis melakukan strategi yang sesuai dengan lingkungan di dalam tapak kawasan. Aspek - aspek yang akan dibahas meliputi: 


\section{Zonasi dan Tata Guna Lahan}

Zonasi lingkungan di desa Sangliat Dol dibagi atas 6 (enam) zona, dengan tujuan untuk membentuk tata ruang desa dengan aktivitas serta arahan pembangunan yang lebih baik dan tepat untuk pengembangan area wisata di desa Sangliat Dol. Pembagian zonasi lingkungan ini memiliki karakternya masing masing, yaitu: Zona 1: Preservasi Inti, Zona 2: Preservasi Penyangga, Zona 3: Transisi Preservasi, Zona 4: Pengembangan Budaya, Zona 5: Koridor Komersial, Zona 6: Hunian dan Konservasi Alam. Berikut akan ditampilkan pada gambar berikut ini:

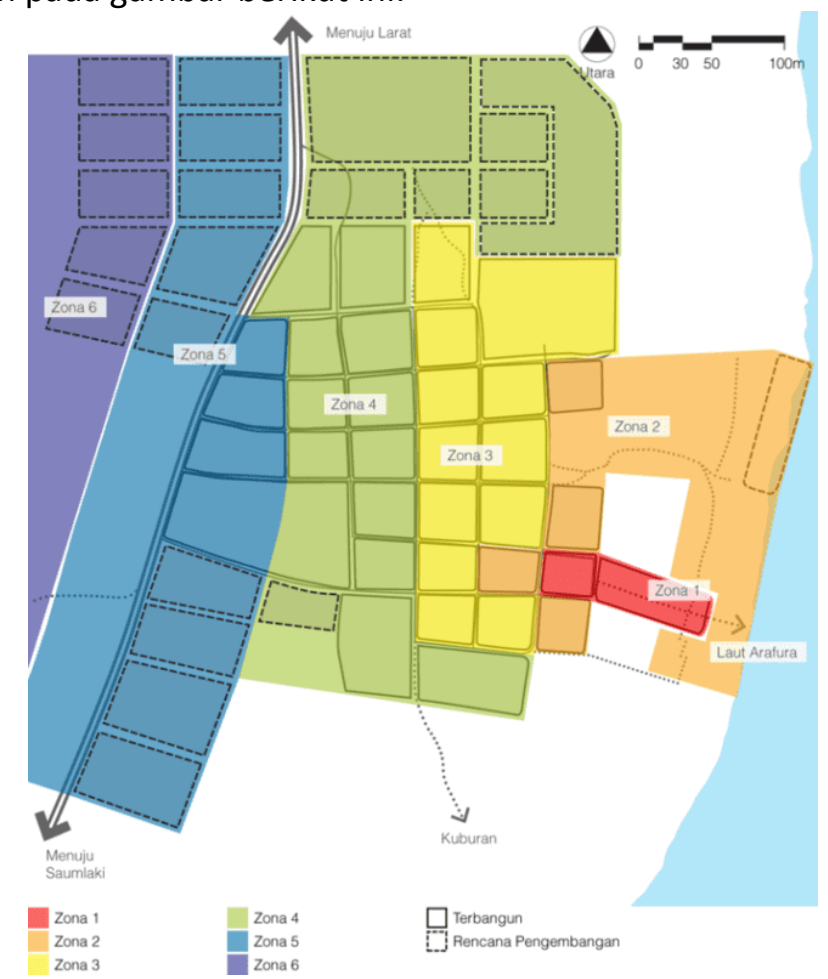

Gambar 7. Konsep Perancangan Zonasi Desa Sangliat Dol

Sumber: Olahan Penulis, 2021

\section{Analisis Best Practice}

Analisis best practice ini bertujuan untuk mengetahui faktor penentu kesuksesan dari objek studi yang dijadikan sebagai benchmarking dengan membandingkan atraksi wisata, fasilitas pariwisata yang terdapat pada studi kasus yang dijadikan benchmarking yang mempunyai karakteristik mirip dengan Kawasan Wisata Cagar Budaya Desa Sangliat Dol. Objek studi yang dipilih untuk dijadikan benchmarking adalah Kawasan Wisata Desa Tradisional Wae Rebo.
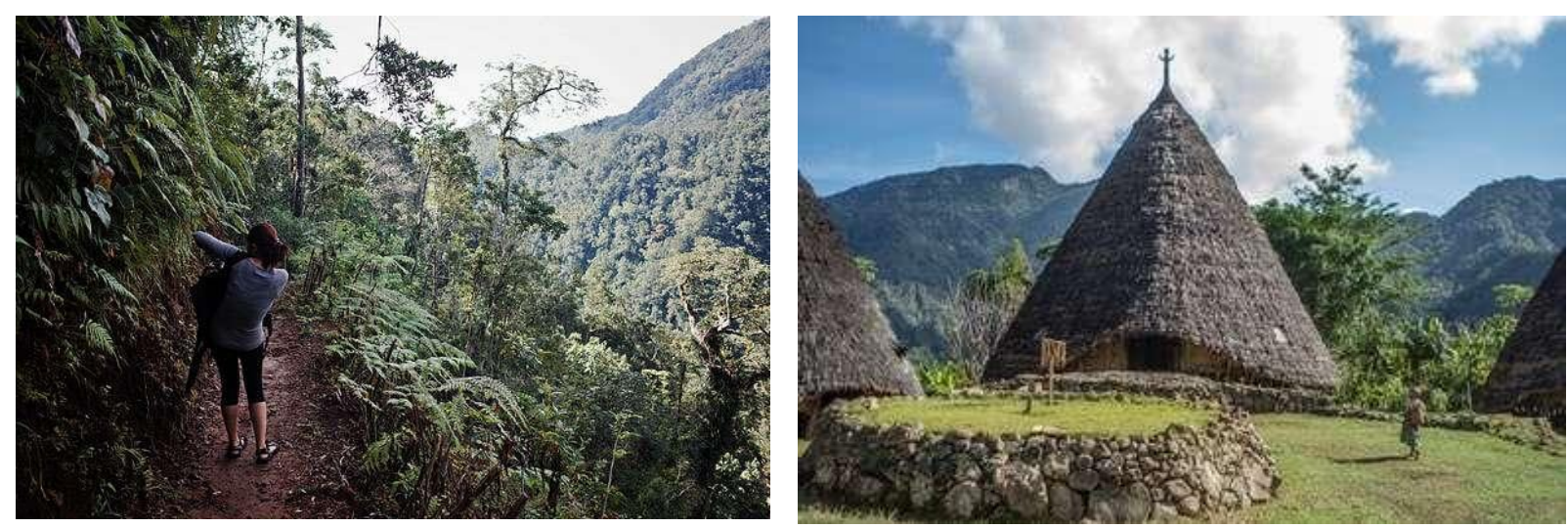

Gambar 8. Kawasan Wisata Desa Tradisional Wae Rebo Sumber : Survey Sekunder 
Pemilihan benchmarking ini dilakukan dengan melihat kriteria yang sesuai dengan objek studi yang diambil dalam penulisan tugas akhir, yaitu kawasan wisata desa budaya yang berhasil dikembangkan dan ditata serta memiliki karakteristik Kawasan wisata desa yang mirip. Berikut merupakan gambaran Kawasan Wisata Desa Tradisional Wae Rebo yang diambil sebagai benchmarking:

Tabel 2. Studi Kasus

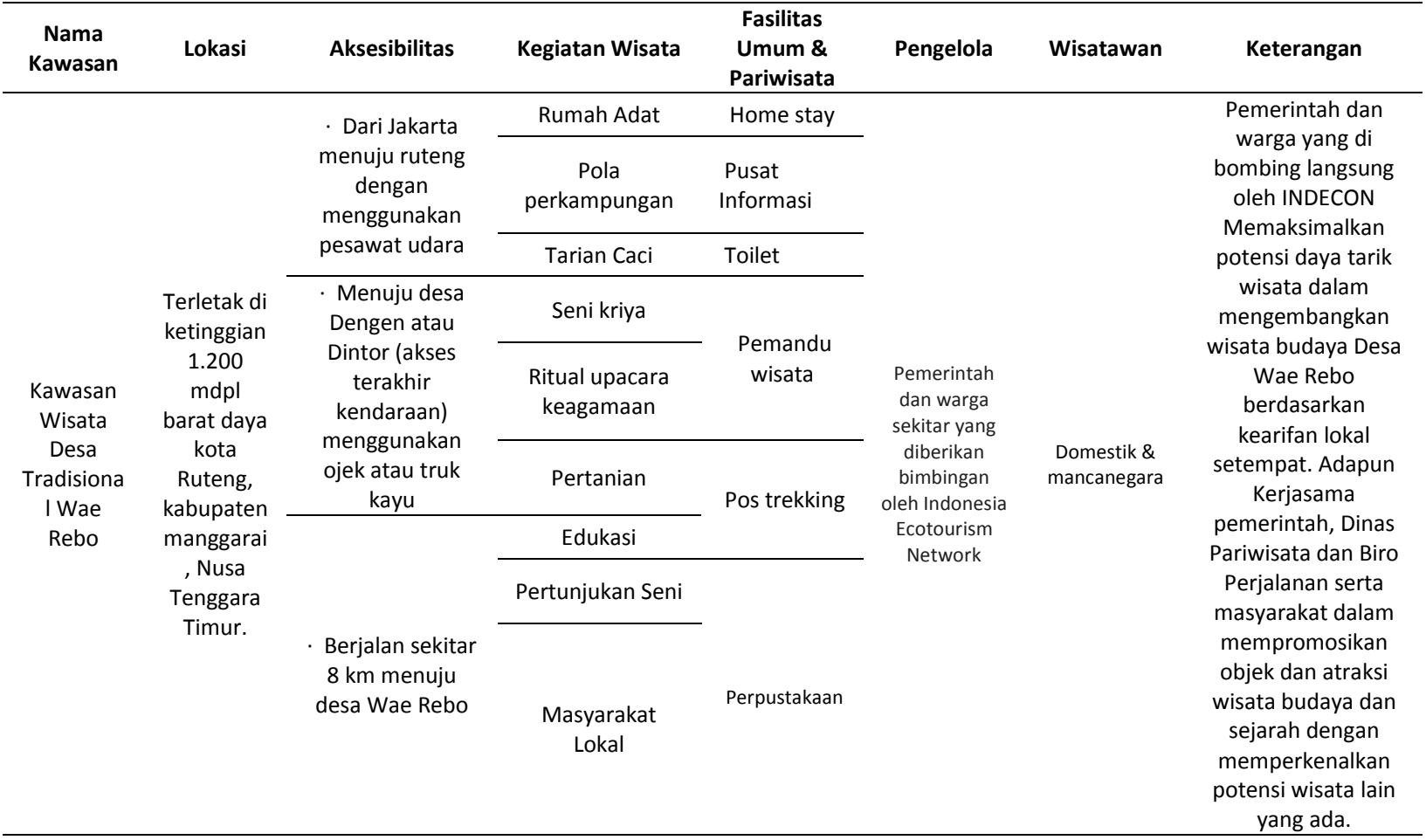

Sumber: Olahan Penulis; 2021

Berdasarkan tabel studi kasus diatas terlihat bahwa Kawasan Wisata Desa Tradisional Wae Rebo memiliki komponen pembangunan kawasan wisata yang dapat diterapkan di objek studi. Kawasan Wisata Desa Tradisional Wae Rebo memiliki keunikan dalam hal bangunan 7 rumah adat yang mengelilingi tempat berkumpul masyarakat. Sedikit berbeda dengan desa Sangliat Dol yang memiliki 6 mata rumah yang mengelilingi situs perahu batu.

Benchmarking tidak hanya membandingkan fasilitas pariwisata dan atraksi wisata tetapi perbandingan juga dilihat dari kriteria kunci keberhasilan dalam pengembangan wisata sejarah dan warisan budaya yang juga akan diterapkan dalam objek studi Kawasan Wisata Cagar Budaya Desa Sangliat Dol. Berikut tabel kriteria kunci keberhasilan dalam pengembangan wisata sejarah dan warisan budaya Benchmarking dilihat berdasarkan Pedoman Pengembangan Wisata Sejarah dan Warisan Budaya menurut Deputi Bidang Pengembangan Industri dan Kelembagaan Kementerian Pariwisata.

Tabel 3. Kesesuaian Benchmark dengan kriteria kunci keberhasilan dalam pengembangan wisata sejarah dan warisan budaya

\begin{tabular}{|c|c|c|c|c|}
\hline No. & Prinsip Dasar & Kriteria & $\begin{array}{l}\text { Wea } \\
\text { Rebo }\end{array}$ & $\begin{array}{l}\text { Objek } \\
\text { Studi }\end{array}$ \\
\hline 1 & Aspek Produk & $\begin{array}{l}\text { Kekuatan signifikansi atau nilai-nilai warisan budaya akan sangat } \\
\text { menentukan dalam melakukan interpretasi, pengembangan produk } \\
\text { wisata, serta dalam merancang jejak warisan budaya dan penguatan } \\
\text { destinasi. Semakin kuat nilai sejarah dan warisan budaya, maka akan } \\
\text { semakin luas cakupan jejak warisan budaya (heritage trail) yang secara } \\
\text { potensial akan memiliki daya magnet yang kuat dalam menarik motivasi } \\
\text { kunjungan. }\end{array}$ & 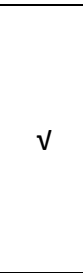 & $\sqrt{ }$ \\
\hline
\end{tabular}




\begin{tabular}{|c|c|c|c|c|}
\hline & & $\begin{array}{l}\text { Orisinalitas dan kelengkapan peninggalan atau bukti fisik terkait dengan } \\
\text { jalur budaya, serta akurasi atau orisinalitas sejarah yang ada sangat } \\
\text { menentukan keunikan dan otentisitas dari produk wisata sejarah dan } \\
\text { warisan budaya. }\end{array}$ & $v$ & V \\
\hline & & $\begin{array}{l}\text { Ketersediaan produk dalam bentuk paket wisata adalah hal yang } \\
\text { menentukan dalam pengembangan wisata sejarah dan warisan budaya. } \\
\text { Paket wisata sejarah dan warisan budaya yang ditawarkan dapat berupa } \\
\text { sebuah rute yang panjang dan lengkap, atau juga rute yang pendek } \\
\text { dalam bentuk penggalan rute utama yang jelas narasinya. }\end{array}$ & $v$ & $\times$ \\
\hline & & $\begin{array}{l}\text { Kemasan produk wisata sejarah dan warisan budaya dalam bentuk } \\
\text { paket wisata yang menarik menjadi sangat penting untuk membidik } \\
\text { pasar yang spesifik atau untuk meluaskan segmen pasar. Pengemasan } \\
\text { produk wisata itu harus disesuaikan dengan motivasi dan juga } \\
\text { karakteristik target wisatawan. }\end{array}$ & V & $x$ \\
\hline \multirow{3}{*}{2} & \multirow{3}{*}{ Aspek Pasar } & $\begin{array}{l}\text { Tren pariwisata global sangat penting dalam memahami gambaran } \\
\text { permintaan dan pemenuhan dalam konteks wisata tematik berbasis } \\
\text { budaya. Dari kajian atas tren pariwisata global tersebut kemudian bisa } \\
\text { diputuskan positioning produk wisata sejarah dan warisan budaya yang } \\
\text { sesuai dengan dinamika pasar dunia masa depan. }\end{array}$ & V & $x$ \\
\hline & & $\begin{array}{l}\text { Analisis pasar mutlak harus dilakukan untuk memastikan segmentasi } \\
\text { wisatawan yang akan menjadi target dari produk wisata sejarah dan } \\
\text { warisan budaya. Apabila target wisatawan jelas, pengembangan produk } \\
\text { wisata sejarah dan warisan budaya akan lebih optimal. Implikasi positif } \\
\text { yang diharapkan adalah peningkatan jumlah kunjungan dan } \\
\text { pembelanjaan wisatawan secara signifikan dengan memperhatikan } \\
\text { aspek keberlanjutan dan bertanggungjawab. }\end{array}$ & V & $x$ \\
\hline & & $\begin{array}{l}\text { Penentuan saluran pemasaran yang tepat akan berpengaruh besar } \\
\text { dalam menjangkau segmen wisatawan dengan motivasi khusus. } \\
\text { Pengembangan saluran pemasaran berbasis media sosial dan digital } \\
\text { efektif bagi wisatawan muda; sedang saluran pemasaran berupa } \\
\text { kegiatan pertukaran budaya (cultural exchange) juga perlu } \\
\text { dikembangkan untuk menyasar komunitas budaya dan minat khusus }\end{array}$ & 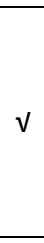 & $x$ \\
\hline \multirow{5}{*}{3} & \multirow{5}{*}{$\begin{array}{c}\text { Aspek Sumber } \\
\text { Daya }\end{array}$} & $\begin{array}{l}\text { Pelibatan masyarakat setempat sebagai tuan rumah menjadi sangat } \\
\text { penting dalam membangun pengalam berinteraksi. Kehidupan } \\
\text { masyarakat setempat yang membuat nilai produk wisata sejarah dan } \\
\text { warisan budaya menjadi lebih hidup. Masyarakat setempat di sini harus } \\
\text { dilihat sebagai pemilik nilai produk wisata sejarah dan warisan budaya. }\end{array}$ & $v$ & V \\
\hline & & $\begin{array}{l}\text { Penguatan kapasitas terhadap kelompok masyarakat setempat dan } \\
\text { komunitas minat khusus dalam pengembangan produk wisata dan } \\
\text { penguatan destinasi menjadi sangat penting. Kapasitasi tersebut } \\
\text { terutama terkait dengan implementasi pelestarian warisan budaya, } \\
\text { serta pengembangan pariwisata berkelanjutan dan bertanggungjawab. }\end{array}$ & V & V \\
\hline & & $\begin{array}{l}\text { Penguatan kapasitas terhadap kelompok masyarakat setempat dan } \\
\text { komunitas minat khusus menjadi pelaku wisata sejarah dan warisan } \\
\text { budaya menjadi krusial untuk keberlanjutan produk sejarah dan warisan } \\
\text { budaya. Kapasitasi bisa berupa penguatan kelompok usaha wisata } \\
\text { berbasis komunitas yang berorientasi pada pengembangan } \\
\text { kewirausahaan sosial (social entrepreneur). }\end{array}$ & $\mathrm{V}$ & $x$ \\
\hline & & $\begin{array}{l}\text { Penguatan kapasitas pelaku wisata berbasis industri untuk mampu } \\
\text { mengembangkan bisnis pariwisata yang berkelanjutan dan bertanggung } \\
\text { jawab menjadi sangat strategis. Selain itu pelaku wisata berbasis industri } \\
\text { didorong untuk bersinergi dengan pelaku wisata berbasis komunitas. }\end{array}$ & V & V \\
\hline & & $\begin{array}{l}\text { Kemampuan pelaku wisata dalam memberikan interpretasi yang kreatif } \\
\text { akan memberikan nilai tambah. Cerita yang disampaikan harus mampu } \\
\text { mengungkapkan sisi lain dari suatu nilai yang sedang dijelaskan. Nilai } \\
\text { yang disampaikan harus bisa merangsang dan melibatkan imajinasi } \\
\text { pikiran wisatawan, serta tidak sekedar menjadi informasi dasar semata }\end{array}$ & V & $\mathrm{V}$ \\
\hline
\end{tabular}




\begin{tabular}{|c|c|c|c|c|}
\hline \multirow{4}{*}{4} & \multirow{4}{*}{ Aspek Destinasi } & $\begin{array}{l}\text { Perlunya zonasi yang jelas dalam perwilayahan di destinasi yang } \\
\text { mengacu pada perencanaan kawasan warisan budaya meliputi zona inti, } \\
\text { pendukung dan pengembangan. Pembangunan destinasi harus } \\
\text { memperhatikan aturan pelestarian terutama pada zona inti dan } \\
\text { pendukung }\end{array}$ & V & $x$ \\
\hline & & $\begin{array}{l}\text { Perencanaan destinasi harus memperhatikan pola pergerakan dari } \\
\text { wisatawan, terutama untuk penyediaan aksesibilitas dan infrastruktur } \\
\text { pendukung kegiatan pariwisata. }\end{array}$ & V & V \\
\hline & & $\begin{array}{l}\text { Pengembangan destinasi harus memperhatikan kemampuan daya } \\
\text { dukung kawasan sesuai aturan pelestarian lingkungan dan budaya. } \\
\text { Pengembangan destinasi wisata sejarah dan warisan budaya yang } \\
\text { berpegang pada prinsip pariwisata berkelanjutan dan } \\
\text { bertanggungjawab }\end{array}$ & $\mathrm{V}$ & V \\
\hline & & $\begin{array}{l}\text { Pengembangan destinasi yang berada pada kawasan adat harus } \\
\text { memperhatikan aturan-aturan adat, serta juga melibatkan para } \\
\text { pemangku adat dalam perencanaan dan pengembangan destinasi. }\end{array}$ & $\mathrm{V}$ & $\mathrm{V}$ \\
\hline \multirow{3}{*}{5} & \multirow{3}{*}{$\begin{array}{l}\text { Aspek } \\
\text { Infrastruktur } \\
\text { Pendukung }\end{array}$} & $\begin{array}{l}\text { Penyediaan infrastruktur pendukung harus memperhatikan aspek } \\
\text { pelestarian lingkungan dan budaya, termasuk penyertaan partisipasi } \\
\text { masyarakat setempat. }\end{array}$ & $\sqrt{ }$ & V \\
\hline & & $\begin{array}{l}\text { Penyediaan infrastruktur pendukung harus memperhatikan kebutuhan } \\
\text { wisatawan, termasuk bagi anak-anak, perempuan, orang tua dan } \\
\text { kelompok berkemampuan khusus }\end{array}$ & $x$ & $x$ \\
\hline & & $\begin{array}{l}\text { Penyediaan infrastruktur pendukung harus bisa merespon } \\
\text { perkembangan teknologi informasi dengan tetap memperhatikan aspek } \\
\text { pelestarian lingkungan dan budaya setempat. }\end{array}$ & $x$ & $x$ \\
\hline \multirow{4}{*}{6} & \multirow{4}{*}{$\begin{array}{l}\text { Aspek Kebijakan } \\
\text { dan Tata Kelola }\end{array}$} & $\begin{array}{l}\text { Dalam konteks pengembangan jejak warisan budaya (heritage trail) } \\
\text { yang melibatkan beberapa wilayah administrasi akan diperlukan sinergi } \\
\text { antar pemangku kepentingan yang diarahkan secara efektif oleh hirarki } \\
\text { di atasnya. }\end{array}$ & $V$ & $x$ \\
\hline & & $\begin{array}{l}\text { Pengelolaan pengembangan wisata sejarah dan warisan budaya harus } \\
\text { memperhatikan aturan pelestarian sesuai tata perundang undangan } \\
\text { yang berlaku termasuk aturan-aturan adat setempat. }\end{array}$ & $\mathrm{V}$ & $\mathrm{V}$ \\
\hline & & $\begin{array}{l}\text { Konsisten dalam menyelenggarakan pengembangan kapasitas dari } \\
\text { sumber daya manusia, baik dalam meningkatkan kualitas interpretasi } \\
\text { maupun kapasitas masyarakat untuk dapat lebih berperan konteks } \\
\text { produk maupun tata kelola }\end{array}$ & $\mathrm{V}$ & $x$ \\
\hline & & $\begin{array}{l}\text { Adanya pemantauan dan evaluasi terhadap pengembangan wisata } \\
\text { tematik berbasis budaya terutama yang terkait dengan produk wisata } \\
\text { sejarah dan warisan budaya. }\end{array}$ & $\mathrm{V}$ & $x$ \\
\hline
\end{tabular}

Sumber : Olahan Penulis, 2021

Dari analisis diatas, objek yang dijadikan benchmarking yakni Kawasan Wisata Desa Tradisional Wae Rebo memiliki kelebihan dan kekurangan masing - masing. Namun dalam penelitian ini akan diambil key success dari objek benchmark tersebut sehingga dapat menjadi pendukung kawasan wisata lainnya sesuai dengan kriteria kunci keberhasilan dalam pengembangan wisata sejarah dan warisan budaya. Berikut ini merupakan kunci sukses dari objek benchmarking yang dapat menjadi acuan di Kawasan Wisata Cagar Budaya Desa Sangliat Dol :Aspek Produk, Aspek Pasar, Aspek Sumber Daya, Aspek Destinasi, Aspek Infrastruktur Pendukung, Aspek Kebijakan dan Tata Kelola.

Selain kriteria kunci keberhasilan dalam pengembangan wisata sejarah dan warisan budaya yang dapat diterapkan dari objek benchmarking, Key success lain yang ingin diterapkan di Kawasan Wisata Cagar Budaya Desa Sangliat Dol adalah dari kegiatan wisata dan fasilitas wisata sehingga penulis dapat menetapkan atraksi wisata dan fasilitas yang perlu ditambahkan di Kawasan Wisata Cagar Budaya Desa Sangliat Dol. Berikut merupakan kegiatan dan fasilitas wisata yang dapat di tambahkan menurut benchmarking : 
Tabel 4. Kegiatan dan Fasilitas Wisata yang dapat diterapkan

\begin{tabular}{cll}
\hline No. & \multicolumn{1}{c}{ Kegiatan Wisata } & Fasilitas Wisata \\
\hline 1 & Rumah Adat & Home Stay \\
\hline 2 & Seni Kriya & Toilet Umum \\
\hline 3 & Edukasi & Pemandu Wisata \\
\hline 4 & Pertunjukan Seni & Perpustakaan \\
\hline 5 & Ritual Upacara Keagamaan & Pusat Informasi \\
\hline & & Sumber : Olahan Penulis, 2021
\end{tabular}

\section{Usulan Pendekatan Pengembangan Wisata Cagar Budaya}

Pada bagian ini akan menganalisis tentang komponen konsep yang akan diajukan yaitu ekowisata. Konsep konsep ekowisata dan potensi wisata di desa Sangliat Dol sendiri memiliki keterkaitan antara satu dengan yang lain dimana potensi wisata cagar budaya merupakan suatu pendalam budaya, karakter, lingkungan dan masyarakat ditambah lagi dengan komponen ekowisata di dalamnya yang diharapkan mampu memperkuat kawasan dari tarik di desa Sangliat Dol, dengan memperhatikan komponen ekowisata yang terdiri dari lima (5) yakni konservasi, masyarakat dan kelembagaan, pendidikan, pasar serta ekonomi. Berikut ini merupakan kriteria dari konsep ekowisata yang dibandingkan dengan kondisi eksisting di kawasan wisata cagar budaya desa Sangliat Dol. Adapun studi potensi wisata cagar budaya ini tidak terlepas dari kesesuaian dengan kebijakan pemerinta terkait seperti Rencana Pembangunan Jangka Menengah (RPJMD) dan vis misi Dinas Kebudayaan dan Pariwisata Kabupaten Maluku Tenggara Barat serta Rencana Induk Pariwisata Nasional (RIPPARNAS) dan visi, misi Kabupaten Kepulauan Tanimbar.

Dengan demikian laporan ini mengacu pada kebijakan - kebijakan yang ada desa Sangliat Dol sangat memiliki potensi yang baik sebagai desa wisata cagar budaya dengan pendekatan ekowisata agar kedepannya dapat menjadi salah satu penghasilan daerah terutama bagi masyarakat setempat.

\section{KESIMPULAN DAN SARAN}

\section{Kesimpulan}

1. Desa Sangliat Dol masuk dalam RIPPARNAS (PP No.50/2011) Kabupaten Maluku Tenggara Barat masuk ke dalam Destinasi Pariwisata Nasional (DPN) Ambon - Banda Naira dan sekitarnya, serta ditetapkan sebagai Kawasan Pengembangan Pariwisata Nasional (KPPN) Tanimbar dan sekitarnya.

2. Rencana Pengembangan Kawasan pariwisata di wilayah Kabupaten Kepulauan Tanimbar dalam RTRW Kabupaten Maluku Tenggara Barat 2012-2032 adalah sebagai Kawasan Wisata Budaya. Kawasan Wisata Budaya dikembangkan di beberapa desa, sebagai desa adat tua yang masih memiliki peran penting dalam struktur budaya Kabupaten Maluku Tenggara Barat salah satu yang tercatat iyalah Desa Sangliat Dol

3. Berdasarkan hasil survey yang dilakukan terdapat benda peninggalan berupa perahu batu, tangga batu dan we lempit. Memiliki nilai budaya yang sangat penting dan menjadi situs tertua di Kabupaten kepulauan Tanimbar.

4. Dengan adanya peninggalan tersebut penulis tertarik melakukan studi potensi wisata dengan mempertimbangkan nilai - nilai budaya yang ada. Sehingga dapat menjadi usulan sebagai Wisata dengan menerapkan Ekowisata berbasis cagar budaya.

5. Dengan adanya konsep ekowisata masyarakat lokal memiliki kesempatan untuk menjadi pelaku dan penyedia jasa wisata dilihat dari kearifan lokal, kegiatan wisata baru yang diusulkan hingga penyediaan akomodasi untuk wisatawan sekaligus menjaga kelestarian kawasan cagar budaya.

6. Kawasan Wisata Desa Tradisional Wae Rebo dijadikan benchmarking sebagai key succes dari objek benchmark tersebut sehingga dapat menjadi pendukung kawasan wisata lainnya sesuai dengan kriteria kunci keberhasilan dalam pengembangan wisata sejarah dan warisan budaya. Berikut ini merupakan kunci sukses dari objek benchmarking yang dapat menjadi acuan di Kawasan Wisata 
Cagar Budaya Desa Sangliat Dol :Aspek Produk, Aspek Pasar, Aspek Sumber Daya, Aspek Destinasi, Aspek Infrastruktur Pendukung, Aspek Kebijakan dan Tata Kelola.

7. Adapun beberapa hal yang menjadi usulan pengembangan yakni seperti: pelestarian rumah adat khas desa Sangliat Dol, pelatihan pemandu, kriya, hari kesenian, memenun, dan tradisi bakar batu.

8. Usulan desa wisata cagar budaya di Desa Sangliat Dol

\section{Saran}

1. Masyarakat harus memanfaatkan potensi Budaya yang ada sehingga tercipta kegiatan wisata di Desa Sangliat Dol agar optimal dan harus sadar akan pentingnya menjaga dan merawat peninggalan benda - benda bersejarah dan menjaga nilai - nilai daya sehingga tetap terjaga sepanjang dan diwariskan turun temurun.

2. Wisatawan harus ikut serta dalam menjaga keberlangsungan pariwisata cagar budaya dengan berkontribusi dan berperilaku positif terhadap benda - benda bersejarah dan alam sekitar Kawasan Wisata Desa Sangliat Dol sebagai salah satu wujud pelestarian budaya.

3. Pemerintah harus terus mendorong wisata cagar budaya sebagai salah satu wisata andalan khususnya di Kabupaten Kepulauan tanimbar sehingga kegiatan pariwisata di Kawasan Desa Sangliat Dol dan sekitarnya berkembang serta mendorong peningkatan PAD (Pendapatan Asli Daerah).

\section{REFERENSI}

Barat, P. K. (2012). RIPARDA. SAUMLAKI: 2012.

Eleanor O. (1977). RESEARCHING A HISTORIC PROPERTY. U.S. Department of the Interior, National Park Service, Cultural Resources, 3.

Indonesia, L. N. (2010, 11 24). Undang - Undang Republik Indonesia No. 11 Tahun 2010 Tentang Cagar Budaya . Retrieved 02 03, 2021, from KEMENDIKBUD: https://jdih.kemdikbud.go.id/arsip/UU_Tahun2010_Nomor11.pdf

KEMENPAR. (2010 - 2025). Provinsi Maluku. Retrieved february 02, 2021, from Peta per wilayah pembangunan 50 destinasi pariwisata nasional : https://www.kemenparekraf.go.id/asset_admin/assets/uploads/media/old_file/lampiran2.p df

kemenparekraf. (2009, january 16). bahwa pembangunan kepariwisataan diperlukan untuk mendorong pemerataan kesempatan berusaha dan memperoleh manfaat serta mampu menghadapi tantangan perubahan kehidupan lokal, nasional, danglobal. Retrieved february 12, 2021,

Pemerintah Daerah Kabupaten Maluku Tenggara Barat. (2012). Rencana Tata Ruang Wilayah Kabupaten Maluku Tenggara Barat 2012 - 2032. Saumlaki: 2012.

Planologi, B. t. (2017, 8-9). Zona, Zoning dan regulation. Retrieved february 02, 2021, Regina Suryadjaja, S.T.,M.T. 
